Int. J. Dev. Biol. 66: 263-267 (2022)

https://doi.org/10.1387/ijdb.210163as

\title{
Expression of D5 dopamine receptors in the lateral ventricle walls during post-weaning rat development
}

\author{
ANTONIS PROSILIS, VASSILIOS MESIAKARIS, ANTONIOS STAMATAKIS* \\ Biology-Biochemistry lab, Faculty of Nursing, School of Health Sciences, \\ National and Kapodistrian University of Athens, Athens, Greece
}

\begin{abstract}
Even before the first synapses appear, neurotransmitters and their receptors are present in the developing brain, regulating the cell fate of neuronal progenitors in neurogenic niches, such as the lateral ventricle. In particular, dopamine appears to play a pivotal role in the neurogenesis of the subventricular zone by controlling the proliferation and differentiation of progenitors through activation of different receptors. Although dopamine receptor 5 (D5R) is expressed prenatally, there is little information regarding its role in either pre- or postnatal forebrain development. To examine the role of D5Rs in neurogenesis in the rat lateral ventricle subventricular zone (V-SVZ), we immunohistochemically defined D5R expression, as well as BrdU incorporation in progenitor cells of various post-weaning stages (Postnatal day (P) 20 until P80). We found that the level of proliferating cells is stable from postnatal day 20 until 50, and then declines sharply on P80. Concomitantly, D5R is expressed in all ages examined, but we detected a progressive decrease in the density of D5R+ cells from P40 until P80. Moreover, double immunostaining for BrdU and D5R revealed that proliferating cells in V-SVZ also express D5R. Collectively, our data suggest that D5R is expressed in the post-weaning V-SVZ of rat at least until P80, and its expression pattern coincides with that of proliferating cells in the V-SVZ, hinting at a possible role of D5Rs in the regulation of neuronal progenitor division/differentiation.
\end{abstract}

KEYWORDS: dopamine, D5R, BrdU, cell cycle, adult neurogenesis

\section{Introduction}

The mammalian adult cerebral cortex displays a distinct cytoarchitecture consisting of layers of morphologically and functionally distinct neurons. Most of these neurons are excitatory glutamatergic cells, and the rest are GABAergic interneurons. During embryonic and early postnatal phases, excitatory neurons are generated from a pool of neural stem cells (NSCs), called Radial Glia (Kriegstein and Alvarez-Buylla, 2009), in two of the many neurogenic zones of the developing brain: the Ventricular Zone (VZ) and the Subventricular Zone (SVZ) (Noctor et al. 2001; Miyata et al. 2001, 2004; Wu et al. 2005). The embryonic VZ is in direct contact with the lateral ventricle, and adjacent to it lies the SVZ. In both areas, neuronal precursors are generated that migrate radially towards the brain surface, shaping the developing cerebral cortex. In the adult mammalian brain, only two neurogenic niches are present: the Ventricular V-SVZ is still active, producing inhibitory and, possibly, glutamatergic neurons; and the Subgranular Zone (SGZ) of the dentate gyrus, generating excitatory neurons (Altman and Das 1965; Doetsch et al. 1999;
Ming and Song 2011; Fuentealba et al. 2012).

Embryonic neurogenesis is a process that is highly regulated by both intrinsic and extrinsic factors. A plethora of extrinsic factors have been identified, which regulate neuronal stem cell fate, with neurotransmitters being recognized as major modulators in shaping various areas of the developing brain, such as the telencephalon and the midbrain (Ohtani et al. 2003; Schlett 2006; Heng et al. 2007; Martins and Pearson 2008). Dopamine is a neurotransmitter that has been shown to affect neuronal precursor proliferation in pre- and postnatal neurogenesis in the SVZ (Baker et al. 2004; Popolo et al. 2004; Kim et al. 2006; Kim et al. 2010), although it is unclear through which receptors dopamine exerts its effects.

Abbreviations used in this paper: ANOVA, analysis of variance; BrdU, bromodeoxyuridine; D5R, Dopamine Receptor 5; E, embryonic day; i.p., intra-peritoneal; LSD, least square differences; NDS, normal donkey serum; NSC, Neural Stem Cell; P, postnatal day; PBS, phosphate-buffered saline; PFA, paraformaldehyde; PFC, Prefrontal Cortex; RT, room temperature; SGV, Subgranular Zone; SVZ, SubVentricularZone; V-SVZ, lateral ventriclesubventricularzone; VZ, VentricularZone.

\footnotetext{
*Address correspondence to: Antonios Stamatakis. Biology-Biochemistry lab, Faculty of Nursing, School of Health Sciences, National and Kapodistrian University of Athens, Papadiamantopoulou 123,GR11527 Athens, Greece. Tel: +302107461453. E-mail: astam@nurs.uoa.gr | web: http://scholar.uoa.gr/astam https://orcid.org/0000-0003-2480-5578
}

Submitted: 20 September, 2021; Accepted: 2 October, 2021; Published online: 26 October, 2021 
There are five different subtypes of dopamine receptors: D1R, D2R, D3R, D4R and D5R.

These are grouped into D1-like (D1 and D5) and D2-like (D2, D3 and D4) receptors. Dopamine receptor mRNAs can be detected in proliferative areas of the dorsal cerebral wall and the ganglionic eminences as early as Embryonic day (E) 12, and most of them continue to be expressed at least until post-natal day $(P)$ 60 in the dorsal and ventral forebrain as well as in SVZ (Araki et al. 2007). A contrasting effect of D1-like and D2-like receptors has been proposed regarding NSC proliferation: D1-like receptor activation in lateral ganglionic eminence and neuroepithelium of the prefrontal cortex (PFC) has anti-mitogenic effects on the precursor cells, whereas D2-like receptor activation results in mitogenic effects (Ohtani et al. 2003; Popolo et al. 2004).

Dopamine 5 receptors (D5R) exhibit a more restricted pattern of expression in the adult rat forebrain compared to D1Rs, and they display increased constitutive activity and affinity for dopamine compared with D1R (Tiberi et al. 1991). Very limited information is available regarding the function of D5R during embryonic or postnatal neurogenesis. Araki et al. (2007) have detected D5R mRNA in the dorsal cerebral wall on E12 (albeit at very low levels), as well as in the SVZ on P60.

Given the scarcity of available data on the involvement of D5R in the regulation of cell divisions in the brain, in the present study, we explored the expression of D5R protein in the walls of the lateral ventricles of the rat brain during post-weaning development (P20-P80), and attempted to associate this expression with on-going cell divisions in this postnatal neurogenic niche.

\section{Results}

\section{BrdU immunolabeling in the V-SVZ during post-weaning development}

NSCs are present in the neurogenic niches of the fetal brain and persist in the two neurogenic zones of the adult brain: the SVZ and the SGZ (Jurkowski et al. 2020). We confirmed the presence of proliferating cells in the SVZ of post-weaning, adolescent, and young adult male rats. Two hours after i.p. administration of the proliferating cell marker BrdU, we observed BrdU ${ }^{+}$cells in the V-SVZ of animals of all ages examined (Fig. 1A). Notably, the average number of V-SVZ BrdU+ cells per section was stable from P20 until P50, while a statistically significant reduction was detected on $\mathrm{P} 80$ compared with all other ages (One-way ANOVA with age as the independent factor $F_{4,14}=15.269$, $p<0.001$; LSD post-hoc P80 vs. P20 $p<0.001$, .vs P30 p<0.001, .vs P40 p<0.001, .vs P50 $p=0.001$, Fig. 1B).

\section{D5 receptor immunolabeling in the V-SVZ during post- weaning development}

The D5 receptor protein was detected, using immunolabeling, in the V-SVZ of post-weaning, adolescent and young adult male rats (Fig. 2A). Interestingly, the number of D5R+ cells per optic field was stable from P20 until P40 and showed a gradual decline thereafter on P50 and P80 (One-way ANOVA with age as the independent factor $F_{4,14}=3.963, p=0.035$; LSD post-hoc P80 vs. P20

A

B $p=0.018$, vs $P 30 p=0.012$, vs $P 40 p=0.010$, vs $P 50 p=0.291$, Fig. $2 \mathrm{~B})$. It should be noted that although the number of D5R+cells per optic field on P50 did not differ significantly from those on P20-P40, the intensity of D5R immunolabeling was lower, indicating a reduction in the levels of D5R expression per V-SVZ cell.

\section{D5 receptor expression on V-SVZ BrdU+ cells}

The presence of both D5R+ and BrdU+cells in the post-weaning V-SVZ prompted us to explore whether cells incorporating BrdU (presumably actively dividing cells) express D5Rs. Thus, using double immunofluorescence, we identified that the majority of BrdU+ cells in the post-weaning V-SVZ (P40) were also D5R+ (98.8 $\pm 0.3 \%$ of BrdU+ cells were also D5R+) (Fig. $2 \mathrm{C}$ ).

\section{Discussion}

Many studies have focused on the factors affecting adult neurogenesis and among others, neurotransmitters have been implicated in its regulation (Banasr et al. 2004; Borta and Höglinger 2007; Pallotto and Deprez 2014; Weselek et al. 2020). In this work,

BrdU immunolabelling
P20

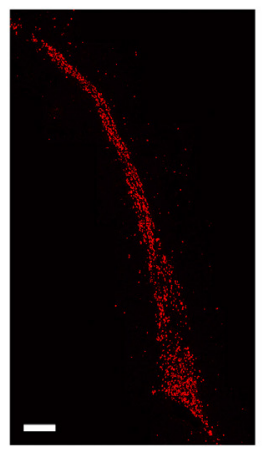

P40

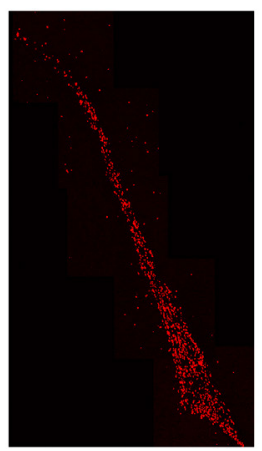

P50

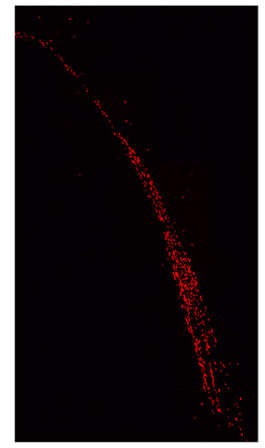

P80

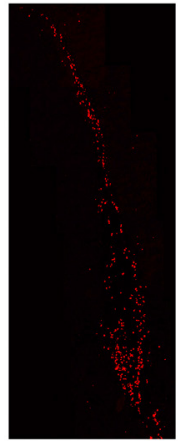

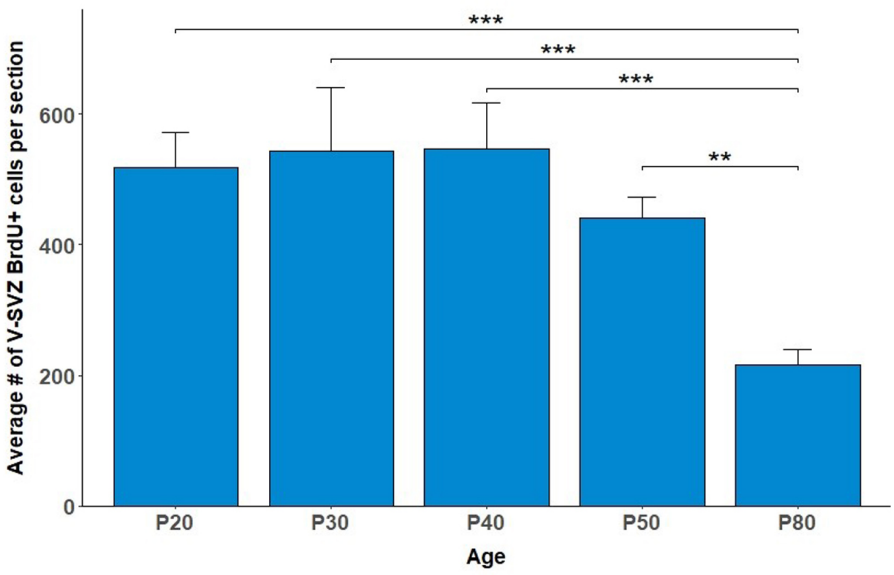

Fig. 1. Pattern of cell divisions in the V-SVZ during post-weaning development. (A) Confocal images of BrdU+ immunopositive cells in the V-SVZ on P20,40,50, and 80 . P, post-natal days. Bar, 200 $\mu \mathrm{m}$. (B) Bar-graphs depicting the number of $\mathrm{V}^{-S V Z} \mathrm{BrdU}^{+}$ cells per section on $\mathrm{P} 20,30,40,50$, and 80 . Values are means $\pm S E M$. $n=3$ per group; One-way ANOVA followed by post-hoc LSD test; ${ }^{\star \star} p=0.001$, ${ }^{\star \star \star} p<0.001$ 
A
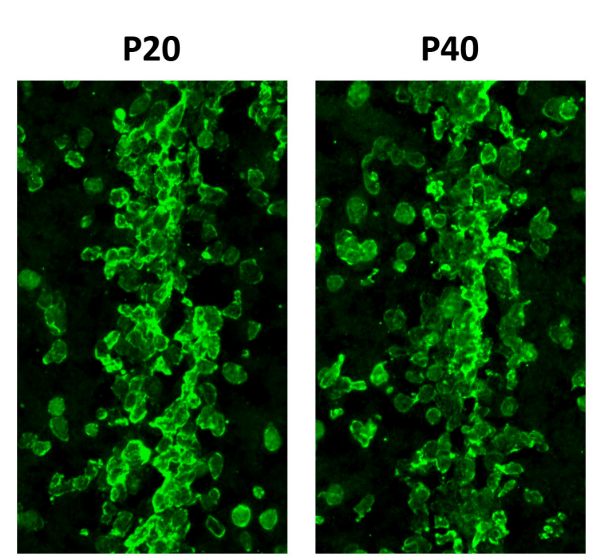

B
D5 Receptors
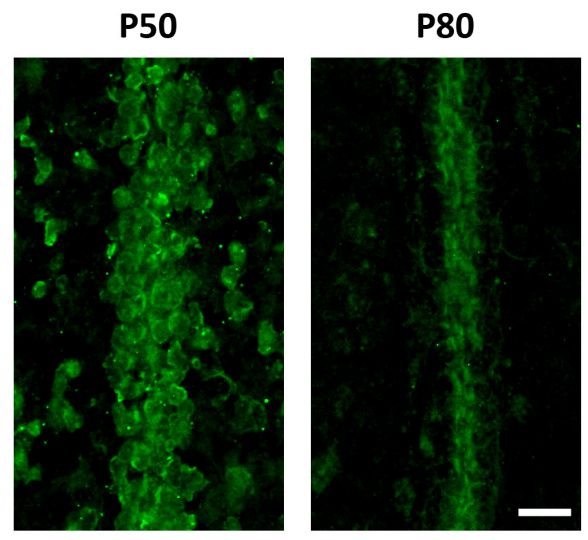

C

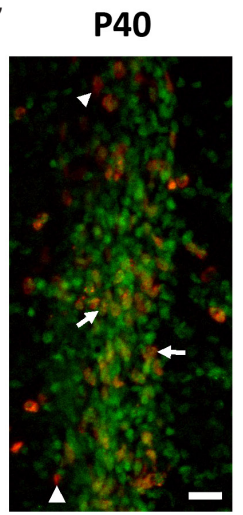

Fig. 2. Pattern of D5R expression in the V-SVZ during post-weaning development. (A) Confocal images of D5R+ immunopositive cells in the V-SVZ on P20, 40, 50, and 80. P, post-natal days. Bar 20 $\mathrm{mm}$. (B) Bar-graphs depicting the number of V-SVZ D5R+cells per optical field on P20, 30, 40, 50, and 80 . Values are means \pm SEM. $n=3$ per group; One way ANOVA followed by post-hoc LSD test; * $p<0.01,{ }^{* *} p=0.01$. ( C Confocal image of D5R+/BrdU+ immunopositive cells in the V-SVZ on P40.

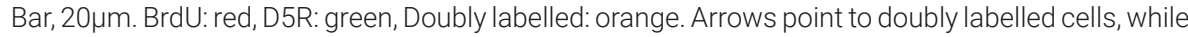
arrowheads to singly BrdU-immunolabeled cells.

we show that in rats between post-weaning and early adulthood, type 5 dopamine receptors are expressed in cells in the V-SVZ of the lateral ventricles, including proliferating ones. Our data corroborate findings from other studies suggesting dopamine as a factor that influences early and adult neurogenesis (Borta and Höglinger, 2007), differentiation in the SVZ (Popolo et al. 2004) and migration (Crandall et al. 2007), by adding a new dopamine receptor type as a possible regulator of the cell fate of NSCs.

More specifically, we confirm the presence of proliferating $(\mathrm{BrdU}+)$ cells in the lateral ventricle at various ages (P20,30, 40, 50 and 80$)$. Notably, the number of $\mathrm{BrdU}^{+}$cells was stable across ages P20-50 and then dropped significantly on P80. Although multiple studies agree that there is a decline of proliferating progenitors between young adult and senescent animals (Tropepe et. al. 1997; Kalamakis et al. 2019), this is the first study, to our knowledge, that investigates the proliferative activity of SVZ in post-weaning and adolescent animals and shows that the proliferative activity in that area declines sometime between P50 and P80.

Although the D5R mRNA has been detected postnatally in the SVZ (Araki et al. 2007), there is limited information regarding the

protein expression and its potential roles in that brain region. We thus defined the distribution of the D5Rs in the walls of the lateral ventricle through the post-weaning period until early adulthood, revealing the presence of D5Rs protein in cells of the rat V-SVZthroughout this developmental period, albeit at a declining level from P40 until P80.

Dopamine receptors in general have been implicated in the regulation of cell proliferation and differentiation in the SVZ, as pharmacological interventions have shown that D1-like receptors regulate NPCs exit from the cell cycle and differentiation, while D2-like receptors maintain NPCs in the cell cycle (Ohtani et al. 2003; Popolo et al. 2005). Nevertheless, the precise dopamine receptor types involved are still undetermined. The similarities in BrdU and D5R staining from P20-80 led us to hypothesize that D5R could regulate the cell fate of NSCs. Indeed, we detected cells in which BrdU and D5R co-localised, strengthening the hypothesis that D5R activation stops the progression of the cell cycle and possibly prepares cells to exit the latter and start the differentiation process.

In summary, our data show that there is proliferative activity and D5R expression in the walls of the lateral ventricle of post-weaning rats that slowly declines in adolescence and early adulthood in a similar pattern. Also, these dividing cells express D5Rs, indicating a possible connection between the two observations. While D5Rs activation could be implicated in the regulation of NSCs proliferation/differentiation, it is certainly part of a broad network of interplaying neurotransmitters as well as other factors determining the production of new cells in the V-SVZ of adolescent and adult rat brain.

\section{Material and Methods}

\section{Animals}

All experiments were carried out in accordance with the ethical recommendations of the European Communities Council Directive of 22 September 2010 (2010/63/EU) and the experimental protocol was approved by the Ethical Committee of the Faculty of Nursing, NKU (\#139/16-1-2015). All experiments were conducted with male Wistar rats that were born and reared in our colony. Rats were kept in $425 \times 266 \times 185 \mathrm{~mm}$ cages (Tecniplast Spa, Italy) with standard wire lid, food and water ad libitum. Standard conditions of $12: 12$ hour light/dark cycle at $22-23{ }^{\circ} \mathrm{C}$ and $45-55 \%$ humidity were maintained in the animal housing facility.

\section{BrdU-administration}

Male Wistar rats were i.p. injected at different developmental stages (Postnatal day (P) 20, 30, 40, 50 and 80), using a 28-gauge 
needle and a $5 \mathrm{ml}$ syringe, with a BrdU-containing saline solution (Biochemica, A2139) (10 $\mu$ l per gr of body weight of a $10 \mathrm{mg} / \mathrm{ml}$ solution). For each of the developmental stages investigated, three males from three different litters were used.

\section{Tissue preparation}

Brains were isolated 2 hours post BrdU injection. Prior to tissue isolation, animals were deeply anaesthetized using isoflurane in a sealed chamber and decapitated. Brains were isolated and immediately transferred in 2-methylbutane in dry ice. Tissues were then stored at $-80^{\circ} \mathrm{C}$ until usage.

Brains were covered in Leica Tissue Freezing Medium(Cat Numb. 14020108926) and placed in a Leica cryostat (CM 1900-1-1) at-15 ${ }^{\circ} \mathrm{C}$. Tissues were dissected into $20 \mu \mathrm{m}$ coronal sections. Sections were collected on silane ( $\mathrm{TCl}, \mathrm{A0439}$ ) coated microscope slides. Multiple sections were placed on each slide (6 slices per slide), with a $120 \mu \mathrm{m}$ interval between sections, to ensure concurrent staining of sections at multiple depths in the region of interest. Slides were stored at $-80{ }^{\circ} \mathrm{C}$ until usage.

\section{BrdU immunostaining}

Slides thawed at room temperature (RT) and then underwent the following procedures: a) submersion in $4 \%$ PFA in PB at $4{ }^{\circ} \mathrm{C}$ for 1 hour, b) washing in $1 \times \mathrm{PBS} \mathrm{pH}=7.4$ at $\mathrm{RT}(3 \times 10 \mathrm{~min}) \mathrm{c}$ ) washing in distilled $\mathrm{H}_{2} \mathrm{O}\left(\mathrm{ddH}_{2} \mathrm{O}\right)(3 \mathrm{X} 10 \mathrm{~min})$, d) transfer in $2 \mathrm{~N} \mathrm{HCl}$ solution at 37 ${ }^{\circ} \mathrm{C}$ for 20 min for DNA denaturation, e) washing in $1 \times \mathrm{PBS} \mathrm{pH}=7.4$ at RT (6X10min) to normalize the $\mathrm{pH}, \mathrm{f})$ washing in $0.4 \%$ Triton $\mathrm{X}$ 100/1x PBS pH=7.4 (2 times for 5 and $10 \mathrm{~min}$ ), g) application of $10 \%$ normal donkey serum(NDS)/0.4\% Triton X-100/1xPBS solution on the slides to block antibody non-specific binding, $h$ ) incubation with mouse anti-BrdU primary antibody (Cell signaling, 5292S), diluted $1: 200$ in $4 \%$ NDS $/ 0.4 \%$ Triton X-100/1x PBS for $48 \mathrm{~h}$ at $4{ }^{\circ} \mathrm{C}$ in a sealed humidity chamber, i) washing in $1 \mathrm{x} \mathrm{PBS} \mathrm{pH}=7.4$ at RT (3X10min), j) incubation with Donkey anti-mouse CF568 secondary antibody (Biotium, Cat Numb. 20105), diluted 1:200 in 2\% NDS/1x PBS at RT in a sealed humidity chamber for $2 \mathrm{~h}, \mathrm{k}$ ) washing with 1x PBS pH=7.4 in the dark (4X10 min) and finally, I) application of fluorescence protecting medium (Biotium, Cat Numb. 23001) and coverslipping. Non-specific staining was negligible as identified on sections incubated in the absence of the primary antibody. Slides were stored at $4^{\circ} \mathrm{C}$ in the dark until they were observed under a confocal microscope (Olympus Fluoview FV1000).

\section{D5R staining}

Slides that contained slices immediately adjacent to those stained for BrdU were left to thaw and were treated as follows: a) submersion in PFA $4 \%$ at $4^{\circ} \mathrm{C}$ for $1 \mathrm{hr}$, b) washing in $1 \times \mathrm{PBS} \mathrm{pH}=7.4$ at RT (4X $10 \mathrm{~min}), \mathrm{c}$ ) washing in $0.4 \%$ Triton $\mathrm{X}-100 / 1 \times \mathrm{PBS} \mathrm{pH}=7.4$ (twice for 5 and $10 \mathrm{~min}$ ), d) blocking of the non-specific antibody binding sites by application of 10\% NDS/0.4\% Triton X-100/1X PBS solution on the slides for $1 \mathrm{~h}$ in a sealed humidity chamber, e) incubation with rabbit anti-D5DR (EMD Millipore Corp., Cat: 324408), diluted $1: 2000$ in $4 \%$ NDS/0.4\% Triton X-100/1x PBS $\mathrm{pH}=7.4$ at $4^{\circ} \mathrm{C}$ in a sealed humidity chamber for $48 \mathrm{~h}, \mathrm{f}$ ) washing in $1 \times$ PBS $\mathrm{pH}=7.4$ at RT (3X10 min each), g) incubation with donkey anti-rabbit CF488A secondary antibody (Biotium, Cat Numb. 20015), diluted $1: 200$ in $2 \%$ NDS/ $1 \times$ PBS $\mathrm{pH}=7.4$ for $2 \mathrm{~h}$ in a sealed humidity chamber, h) washing with $1 \times \mathrm{PBS} \mathrm{pH}=7.4$ (4X $10 \mathrm{~min}$ ) and application of fluorescence protecting medium and a coverslip on the slides. Non-specific staining was negligible as identified on sections incubated in the absence of the primary antibody. Slides were stored at $4^{\circ} \mathrm{C}$ in the dark until they were observed under a confocal microscope (Olympus Fluoview FV1000).

\section{D5R/BrdU double immunostaining}

Three animals on PND40 were i.p. injected with BrdU, and 2 $\mathrm{h}$ later were deeply anesthetized with isoflurane, transcardially perfused with PB pH=7.4, and then with 4\% PFA in PB (both solutions at $4^{\circ} \mathrm{C}$ ). Brains were dissected, transferred to $4 \%$ PFA in PB overnight at $4^{\circ} \mathrm{C}$, and stored at $-80^{\circ} \mathrm{C}$. Sectioning was performed at $-25^{\circ} \mathrm{C}$ into $40 \mu \mathrm{m}$ thick coronal sections. Sections were collected in $1 \mathrm{x}$ PB pH 7.4 (up to 6 sections per well with a $120 \mu \mathrm{m}$ interval between sections) and kept at $4^{\circ} \mathrm{C}$ until further processed. The protocol described above for BrdU was employed, and sections were incubated for 3 overnights with both antibodies (anti-BrdU and anti-D5R) as described above. Following incubation with the primary antibodies, sections were incubated at the same time with both secondary antibodies, as described above, coverslipped and examined under a confocal microscope (Olympus Fluoview FV1000).

\section{Quantification of BrdU+, D5R+ and D5R/BrdU double labeled cells}

From each brain and for each antigen or combination of antigens, three sections were randomly but systematically selected within the following antero-posterior extent: $2.20-2.60$, with a spacing of $120 \mu \mathrm{m}$. For BrdU+ quantification, all immunolabeled cells were counted in the V-SVZ of each hemisphere. For D5R+ quantification, immunostained cells were counted in the medial part of V-SVZalong the dorso-ventral axis of the brain. For D5R/BrdU colocalization, the number of doubly stained cells, as well as that of all BrdU+ cells, was counted in the medial part of V-SVZ along the dorso-ventral axis of the brain, and the \% of BrdU+ cells that were also D5R+ was calculated. All measurements were performed by two independent observer; their correlation was $>95 \%$. For all measurements, the average value was calculated for each animal.

\section{Statistical analyses}

The effect of age on the number of V-SVZ BrdU+ cells/section or D5R+ cells/optical field was determined with one-way analysis of variance (ANOVA) tests with age as the independent factor, followed by least square differences (LSD) post-hoc comparisons between different age groups, using the SPSS v.26 software. The level of statistical significance was set at $p=0.05$.

\section{References}

ALTMAN J., DAS G. D. (1965). Autoradiographic and histological evidence of postnatal hippocampal neurogenesis in rats. The Journal of Comparative Neurology 124: 319-335. https://doi.org/10.1002/cne.901240303

ARAKI K. Y., SIMS J. R., BHIDE P. G. (2007). Dopamine receptor mRNA and protein expression in the mouse corpus striatum and cerebral cortex during pre- and postnatal development. Brain Research 1156: 31-45. https://doi.org/10.1016/j. brainres.2007.04.043

BAKER S. A., BAKER K. A., HAGG T. (2004). Dopaminergic nigrostriatal projections regulate neural precursor proliferation in the adult mouse subventricular zone. European Journal of Neuroscience 20: 575-579. https://doi.org/10.1111/j.14609568.2004.03486.x

BANASR M., HERY M., PRINTEMPS R., DASZUTA A. (2004). Serotonin-Induced Increases in Adult Cell Proliferation and Neurogenesis are Mediated Through Different and Common 5-HT Receptor Subtypes in the Dentate Gyrus and the 
Subventricular Zone. Neuropsychopharmacology 29: 450-460. https://doi. org/10.1038/sj.npp.1300320

BORTA A., HÖGLINGER G. U. (2007). Dopamine and adult neurogenesis. Journal of Neurochemistry 100: 587-595. https://doi.org/10.1111/j.1471-4159.2006.04241.x

BRILL M. S., NINKOVIC J., WINPENNY E., HODGE R. D., OZEN I., YANG R., LEPIER A., GASCÓN S., ERDELYI F., SZABO G., PARRAS C., GUILLEMOT F., FROTSCHER M., BERNINGER B., HEVNER R. F., RAINETEAU O., GÖTZ M. (2009). Adult generation of glutamatergic olfactory bulb interneurons. Nature Neuroscience 12: 1524-1533. https://doi.org/10.1038/nn.2416

DOETSCH F., CAILLÉ I., LIM D. A., GARCÍA-VERDUGO J. M., ALVAREZ-BUYLLA A. (1999). Subventricular Zone Astrocytes Are Neural Stem Cells in the Adult Mammalian Brain. Cell 97: 703-716. https://doi.org/10.1016/S0092-8674(00)80783-7

FUENTEALBA L. C., OBERNIER K., ALVAREZ-BUYLLA A. (2012). Adult Neural Stem Cells Bridge Their Niche. Cell Stem Cell 10: 698-708. https://doi.org/10.1016/j. stem.2012.05.012

HENG J. I.T., MOONEN G., NGUYEN L. (2007). REVIEW ARTICLE: Neurotransmitters regulate cell migration in the telencephalon. European Journal of Neuroscience 26: 537-546. https://doi.org/10.1111/j.1460-9568.2007.05694.x

JURKOWSKI M. P., BETTIO L., K. WOO E., PATTEN A., YAU S.Y., GIL-MOHAPEL J. (2020). Beyond the Hippocampus and the SVZ: Adult Neurogenesis Throughout the Brain. Frontiers in Cellular Neuroscience 14: 293. https://doi.org/10.3389/ fncel.2020.576444

KALAMAKIS G., BRÜNE D., RAVICHANDRAN S., BOLZ J., FAN W., ZIEBELL F., STIEHL T., CATALÁ-MARTINEZ F., KUPKE J., ZHAO S., LLORENS-BOBADILLA E., BAUER K., LIMPERT S., BERGER B., CHRISTEN U., SCHMEZER P., MALLM J. P., BERNINGER B., ANDERS S., DEL SOL A., MARCINIAK-CZOCHRA A., MARTIN-VILLALBA A. (2019). Quiescence Modulates Stem Cell Maintenance and Regenerative Capacity in the Aging Brain. Cell 176: 1407-1419.e14. https:// doi.org/10.1016/j.cell.2019.01.040

KIM, S. Y., CHOI, K. C., CHANG, M. S., KIM, M. H., KIM, S. Y., NA, Y. S., LEE, J. E., JIN, B. K., LEE, B. H., BAIK, J. H. (2006). The Dopamine D2 Receptor Regulates the Development of Dopaminergic Neurons via Extracellular Signal-Regulated Kinase and Nurr1 Activation. The Journal of neuroscience : the official journal of the Society for Neuroscience 26: 4567-4576. https://doi.org/10.1523/JNEUROSCI.5236-05.2006

KIM Y., WANG W.Z., COMTE I., PASTRANA E., TRAN P. B., BROWN J., MILLER R. J., DOETSCH F., MOLNÁR Z., SZELE F. G. (2010). Dopamine stimulation of postnatal murine subventricular zone neurogenesis via the D3 receptor. Journal of Neurochemistry 114:750-760. https://doi.org/10.1111/j.1471-4159.2010.06799.x

MARTINS R. A.P., PEARSON R. A. (2008). Control of cell proliferation by neurotransmitters in the developing vertebrate retina. Brain Research 1192: 37-60. https:// doi.org/10.1016/j.brainres.2007.04.076

MING G., SONG H. (2011). Adult Neurogenesis in the Mammalian Brain: Significant Answers and Significant Questions. Neuron 70:687-702. https://doi.org/10.1016/j. neuron.2011.05.001
MIYATA T., KAWAGUCHI A., OKANO H., OGAWA M. (2001). Asymmetric Inheritance of Radial Glial Fibers by Cortical Neurons. Neuron 31: 727-741. https://doi. org/10.1016/S0896-6273(01)00420-2

MIYATA T., KAWAGUCHI A., SAITO K., KAWANO M., MUTO T., OGAWA M. (2004). Asymmetric production of surface-dividing and non-surface-dividing cortical progenitor cells. Development 131:3133-3145. https://doi.org/10.1242/dev.01173

NOCTOR S. C., FLINT A. C., WEISSMAN T. A., DAMMERMAN R. S., KRIEGSTEIN A. R. (2001). Neurons derived from radial glial cells establish radial units in neocortex. Nature 409: 714-720. https://doi.org/10.1038/35055553

OHTANI N., GOTO T., WAEBER C., BHIDE P. G. (2003). Dopamine Modulates Cell Cycle in the Lateral Ganglionic Eminence. The Journal of Neuroscience 23: 28402850. https://doi.org/10.1523/JNEUROSCI.23-07-02840.2003

PALLOTTO M., DEPREZ F. (2014). Regulation of adult neurogenesis by GABAergic transmission: signaling beyond GABAA-receptors. Frontiers in Cellular Neuroscience 8: 166. https://doi.org/10.3389/fncel.2014.00166

POPOLO M., MCCARTHY D. M., BHIDE P. G. (2004). Influence of Dopamine on Precursor Cell Proliferation and Differentiation in the Embryonic Mouse Telencephalon. Developmental Neuroscience 26: 229-244. https://doi.org/10.1159/000082140

SCHLETT K. (2006). Glutamate as a Modulator of Embryonic and Adult Neurogenesis. Current Topics in Medicinal Chemistry 6: 949-960. https://doi. org/10.2174/156802606777323665

TIBERI M., JARVIE K. R., SILVIA C., FALARDEAU P., GINGRICH J. A., GODINOT N., BERTRAND L., YANG-FENG T. L., FREMEAU R. T., CARON M. G. (1991). Cloning, molecular characterization, and chromosomal assignment of a gene encoding a second D1 dopamine receptor subtype: differential expression pattern in rat brain compared with the D1A receptor. Proceedings of the National Academy of Sciences 88: 7491-7495. https://doi.org/10.1073/pnas.88.17.7491

TROPEPE V., CRAIG C. G., MORSHEAD C. M., VAN DER KOOY D. (1997). Transforming Growth Factor-a Null and Senescent Mice Show Decreased Neural Progenitor Cell Proliferation in the Forebrain Subependyma. The Journal of Neuroscience 17: 7850-7859. https://doi.org/10.1523/JNEUROSCI.17-20-07850.1997

WESELEK G., KEINER S., FAUSER M., WAGENFÜHR L., MÜLLER J., KALTSCHMIDT B., BRANDT M. D., GERLACH M., REDECKER C., HERMANN A., STORCH A. (2020). Norepinephrine is a negative regulator of the adult periventricular neural stem cell niche. Stem Cells 38: 1188-1201. https://doi.org/10.1002/stem.3232

WU S.X., GOEBBELS S., NAKAMURA K., NAKAMURA K., KOMETANI K., MINATO N., KANEKO T., NAVE K.A., TAMAMAKI N. (2005). Pyramidal neurons of upper cortical layers generated by NEX-positive progenitor cells in the subventricular zone. Proceedings of the National Academy of Sciences 102:17172-17177. https:// doi.org/10.1073/pnas.0508560102

YAN Z., SURMEIER D.J. (1997). D5 Dopamine Receptors Enhance Zn2+-Sensitive GABAA Currents in Striatal Cholinergic Interneurons through a PKA/PP1 Cascade. Neuron 19: 1115-1126. https://doi.org/10.1016/S0896-6273(00)80402-X 